\title{
New paradigm in witchcraft issues: A strategic procedure for sustainable development in Nigeria
}

\author{
Anthonia M. Essien and Victor Effiong Ben \\ Department of Religious and Cultural Studies, Department of Sociology/Anthropology \\ University of Uyo, Uyo, Akwa Ibom State, Nigeria
}

\begin{abstract}
There is increasing believe in and fear of witchcraft among the people of Southeast Nigeria. Certain efforts made by people including the lives of both young and old are believed to be at the mercy of witches and wizards. Notwithstanding the raining church and prophetic activities in the region which have to a large extent assuaged the feelings as well as heightened the hope of majority of the people, there is still doubt in the minds of Christians concerning freedom from the infliction of witches and wizards. This study focuses on developing new paradigms in the issues of witchcraft from a sociological and religious perspective. It concentrated in Akwa lbom and Anambra States, all located in the Southeast Nigeria. The study collected data from 1500 respondents randomly selected from a population of Orthodox and Pentecostal Churches in the two States. The data were based on the socio-economic and religious practices of the people. However, using the two stage ordinary least square regression, the study discovered a strong and direct influence of witches and wizard on income level, health conditions, success, favour and level of stress by the people. The study equally observed a false perception of powers of witches and wizards among the people in the region given the results of the bivariate and multivariate analysis which show a weak, very weak and inverse relationship between the measured variables. This false perception based on the findings of the study impedes economic growth and development, political and social progress in many ways in the region. Consequently, the study recommends effective roles of Exorcists and advocates the power of positive thinking and self-belief as powerful weapon to fight imaginary and real witches.
\end{abstract}

Keywords: Witchcraft, Nigeria, prophetic activities

\section{INTRODUCTION}

Nigerians are a very religious people, they recourse to God and to their religious leaders in moments of distress as much as in moments of joy and success (Ehusani 1996). The religious situation of Nigeria reveals a nation super saturated with Churches. In every nook and cranny of the country, voices are heard by day and night announcing Jesus as the answer (Obiora 1998); one may add: to all human and spiritual problems. Nigeria has also been the site for Pentecostalism's greatest explosion on the African Continent, and the movement's extraordinary growth shows no signs of slowing (Marshall 2009). The massive explosion of churches in Nigeria has been of scholarly interest (Ukah 2008, Ojo,1986; Marshall 1991; 1992;1993; 1995, Asamoah-Gyadu, 1998; Cox 1994). It is to the churches that most Nigerians look up for a number of issues :

True leadership in the struggle for social transformation and national regeneration (Ehusani
1996), Resolution of social and political conflicts (Okai 2008) Healing of physical and spiritual ailments (Essien 1999), Economic breakthroughs for prosperity (Obiora 1998), Salvation from every human and spiritual attacks (Enang 1979). Liberation from the powers of witches (Udoh 2008)

Since the focus of this study is on the belief of the people of Southeast Nigeria on witches and how these affect their lives, we shall be concentrating on the liberating powers of the churches from the belief in witchcraft. The socio-cultural belief in southeast Nigeria where this research is focused is that every misfortune, deaths, sicknesses are caused by witches. The belief in witches have a prominent place in the spirituality of the people of Southeast Nigeria. Witches are mostly feared because of the belief in the anti social problems associated with them (Irvine 2005). Spiritual Leaders are also believed to have the antidote for solving these supernatural problems. This offers a lucrative business to church leaders who believe they have 
powers to handle the witchcraft issues. Consequently, the founders and spiritual leaders of some churches often claim divine authenticity, divine mandate directly from God (Obiora 1998) to solve these problems and to be presenting a better and purified version of Christianity.

In Southeast Nigeria, the range of activities of witches is considered deleterious, destroying life primarily through mysterious wasting diseases, and eating of the soul of their victims thereby causing death. Witchcraft issues are difficult to handle as everything connected with witchcraft takes place in a fantasy realm which is, almost ex hypothesis, intangible and beyond empirical verification (Udoh 2008). Witches are considered a serious threat to the entire community. Witchcraft is believed to be a very common practice in Southeast Nigeria that even children are often believed to be members who cause serious havoc to their families. As religious as the people of Southeast Nigeria are, they subscribe to the killing of witches according to the literally interpretation of Exodus 22:18 "thou shall not suffer a witch to live".

The purpose of this paper therefore is to advocate a new paradigm in the issues of witchcraft from a sociological and religious perspective. The antecedent being that many of these churches battle with the issues of witchcraft with the sole aim of delivering the adherents from its suppressing antisocial influence. This study unveils the fact that although witches may exist, most of the human problems attributed to witches are not necessarily accurate. There are more fundamental causes of human problems namely poverty, ignorance, poor health facilities, worldview, poor governance, failure of the churches in authentic prophetic ministry, unemployment, youths restiveness, as well as the proliferation of churches which equal commercialization of religion and the self enrichment of the purveyors of prayers and miracles for money and prosperity in Southeast Nigeria (Okere 2005). While not denying the existence of witches, the undue attribution of most human factors to the powers of witches, questions the very activities of the churches in the light of their prophetic role.

\section{METHODOLOGY OF THE STUDY}

The design of this study was both qualitative and quantitative. The study used the survey design which fits the investigation of a large and heterogeneous population. Data were collected from 1500 respondents, aged 5-65 years, using the stratified random sampling procedure. The respondents comprised persons who have had experience of witchcraft, have been victim of attack or labeling and could give useful information about witches and wizards from their Christian background and traditional experiences.

The study was focused on two states in the southeast Nigeria. The Southeast Nigeria is made up of eleven states, and the two states selected for the study included Akwa Ibom State and Anambra State. Three Local Government Areas (one per Senatorial District) were chosen from each of the states. The choice was based on histories of witchcraft activities, proliferation of churches and media reports on notoriety of the pandemonium in the areas. Thus, Uruan, Abak and Okobo Local Government Areas were selected from Akwa Ibom State while in Anambra State, Njikoka, Onitsha South and Awka South Local Government Areas were selected.

In the study, each church constituted a stratum, and twenty-five churches were selected from each local government area. The churches were grouped under orthodox and Pentecostals. From the Orthodox group, five- churches were selected and from the Pentecostal group, twenty churches were selected using simple random sampling method. That is, the lists of the registered Orthodox and Pentecostal churches was obtained from the Corporate Affairs Commission (CAC) separately in the two states. From the list, the fish bowl method was used to select the churches from the two groups.

The study also selected 10 respondents from each stratum (church); totaling 250 respondents in each Local Government Area. The information given by the respondents were coded and presented in tables to illustrate the distribution of the respondents by their social and economic characteristics. The data were also, adjusted on two- stage least square regression.

\section{Data and Result}

The study concentrated primarily on investigating the powers of the church and belief of members about power of witchcraft. Ardent Christians were selected as respondents. It was assumed that a strong spiritual disposition is not without materials endowment; since faith without work is dead (James $2: 23$ ). Christians and all others who go to the church are full of expectations of meeting desired needs and accomplishment of fulfilled life.

It is the perception of most people in the two states focused in the study just as Ogunjuyigbe (2004) 
observed among the Yoruba's; Offiong (1983) and Umanah (1996) equally observed among the Ibibio; the powers of witches and wizards manifest negatively on an individual, leading to poor health, failure in life, disappointment and problems of many kinds among others. Witchcraft constitutes the greatest challenge to prayers besides being the main cause for spiritual invocations among Christians. Witchcraft from all indications is wicked: wishing no person any good in life. Efforts made by people unlucky to be attacked by witches and wizards is frustrated still man is in great needs of wants. As postulated by Abraham Maslow (1943) cited in Essien (1999) human desires for the psychological needs, belongingness, safety and self actualization are important. These translate, into good health, success, absence of stress, achievement, and favour. Among the study population, everyone looks onto God for His benevolent in this direction. Prayers and spiritual invocations are dependable instruments in which, as in every part of the world, the study population used to invoke God's wrath on witches and wizards that confront their health status and success. As earlier noted, the study population is of the belief that witches and wizards frustrate chances of favour, cause stress, and ruin, no matter the income level of the individual or family.

These data describe the background characteristics of the respondents; the two- stage least square regression results explains the effect of witchcraft on the determinants of Christian beliefs about witchcraft, namely income, good health, success, favour and stress. Table 1: shows the percentage distribution of respondents by age. The table shows that the highest number of respondents $405(27 \%)$ were sampled in the age group of 45-54 years. A total of 102 (6.8\%) respondents, being the least, were sampled in the age group of 15-24 years. According to data in the table, $153(10.2 . \%)$ respondents were sampled in the lowest age group of 5-14 years while 93 (62.\%) respondents were sampled among persons 65 years and above.

Table 2 shows that the least number of respondents $40(2.7 \%)$ were sampled in the semi-urban area of Onitsha South in Anambra State. The Rural Area of Okobo in Akwa Ibom State on the contrary produced the highest number of respondents 157 (10.4. \%) irrespective if the fact that sampling was fair and utmost random. In Akwa Ibom, it was only in Abak Local Government that sampling was carried out in the urban. In Anambra, samplings were carried out in the urban areas of Onitsha South and Awka. The urban, semi-urban and rural areas classification of the study area is based on the state of development of the areas.

Table 3 indicates that among the male respondents, the highest, $167(66.8 \%)$ were sampled in Uruan area of Akwa Ibom state while the least 67 (26.8\%) were sampled in Njikoka in Anambra State. Among the female respondents, the reverse was the case (see in table 3). According to the table, equal number of respondents 125 (50\%) males and females were sampled in Abak areas of Akwa Ibom State

Table 4 shows that high monthly income was reported by less number of respondents, 164 (21.9\%) in Akwa Ibom State and 193 (25.7\%) in Anambra State. In Akwa Ibom State, medium level monthly income was reported by majority of the respondents as was the case in Anambra State

Table 5 shows the distribution of the respondents in each church and by level of educational attainment. The table indicates that $132(8.8 \%)$ of the total sampled respondents have no formal education while $462(30.8 \%)$ respondents reported, have acquired a University education. Among the highly educated respondents, the largest, $46(76.67 \%)$ were adherent of Full Gospel Church of God. The Jehovah's Witnesses constituted the largest number of respondents, $44(73.33 \%)$ that were sampled among those who reported a higher educational attainment. Higher education was defined by completion of ordinary and or higher diploma, college of education, or polytechnic education. Among the respondents who admitted finishing secondary school, the New Covenant constituted the largest, 36 (60\%), whereas the Liberty Gospel Ministry worshippers constituted the largest $33(55 \%)$ among the respondents who reported have only attended formal education up to the primary level.

Table 6 shows the result of Two Stage ordinary leastSquare regression analysis. The results are presented for univariate, bivariate and multivariate analysis respectively. Five variables or factors assumed in the study that influenced the respondents desired for or attitude to prayer and spiritual innovations constituted the (main) subjects on which data were elicited from the respondents. To test the variables, the regression equation was formed substituted with the variables. The equation is given as: $\mathrm{Pl}_{\mathrm{l}}=\mathrm{a}+\mathrm{t}_{1} \mathrm{X}_{1}+\mathrm{t}_{2} \mathrm{X}_{2}+\mathrm{t}_{3} \mathrm{X}_{\mathrm{l}_{3}}+\mathrm{tt}_{4} \mathrm{X}_{4}+\mathrm{tt}_{5} \mathrm{X}_{5}$ 
Am. J. Soc. Mgmt. Sci., 2011, 2(1): 47-55

Table 1: Age distribution of the respondents

\begin{tabular}{|l|l|l|}
\hline Age group & No of Respondents & Percentage \\
\hline $5-15$ & 153 & 10.2 \\
\hline $15-24$ & 102 & 6.8 \\
\hline $25-34$ & 225 & 15. \\
\hline $35-44$ & 377 & 25.1 \\
\hline $45-54$ & 405 & 27 \\
\hline $55-64$ & 145 & 9.7 \\
\hline $65+$ & 93 & 6.2 \\
\hline Total & 1500 & 100 \\
\hline
\end{tabular}

Table 2: Distribution of the respondents by Place of Residence

\begin{tabular}{|l|c|c|}
\hline $\begin{array}{l}\text { Place of residence by State and Local } \\
\text { Government }\end{array}$ & No of Respondents & Percentage \\
\hline Akwa Ibom- Uruan- Rural Area & 138 & 9.2 \\
\hline Semi- Urban & 112 & 7.5 \\
\hline - Abak- Rural Area & 150 & 10 \\
\hline Urban & 100 & 6.7 \\
\hline - Okobo- Rural Area & 157 & 10.4 \\
\hline Semi-Urban & 93 & 6.2 \\
\hline Anambra- Njikoka- Rural Area & 143 & 9.5 \\
\hline Semi-Urban & 107 & 7.1 \\
\hline Onitsha South- Rural Area & 96 & 6.4 \\
\hline \multicolumn{1}{|c|}{ semi-urban } & 40 & 2.7 \\
\hline Urban Area & 114 & 7.6 \\
\hline Awka- Rural Area & 75 & 5 \\
\hline Semi-Urban & 54 & 3.6 \\
\hline Urban Area & 121 & 8.1 \\
\hline Total & 1500 & 100 \\
\hline
\end{tabular}

Table 3 : Sex Distribution of the respondents by States and Local Government Area

\begin{tabular}{|l|l|l|l|l|l|l|}
\hline \multicolumn{2}{|c|}{ Akwa Ibom State } & \multicolumn{2}{c|}{ Anambra State } \\
\hline Sex & Uruan & Abak & Okobo & Njikoka & Onitsha & Awka \\
\hline Male & $167668 \%$ & $12550 \%$ & $11445.6 \%$ & $6726.8 \%$ & $15461.6 \%$ & $11746.8 \%$ \\
\hline Female & $8333.2 \%$ & $12550 \%$ & $13654.4 \%$ & $18373.2 \%$ & $96384 \%$ & $13353.2 \%$ \\
\hline Total & 250 & 250 & 250 & 250 & 250 & 250 \\
\hline
\end{tabular}


Am. J. Soc. Mgmt. Sci., 2011, 2(1): 47-55

Table 4 Income Level of the respondents by States and Local Government Areas

\begin{tabular}{|l|l|l|}
\hline \multicolumn{1}{|c|}{ Income Level } & No of Respondents & Percentage \\
\hline Akwa Ibom- Uruan- Low & 75 & 30 \\
\hline Medium & 129 & 51.6 \\
\hline High & 46 & 18.4 \\
\hline Abak-Low & 110 & 44 \\
\hline Medium & 101 & 40.4 \\
\hline High & 39 & 15.6 \\
\hline Okobo- Low & 49 & 19.6 \\
\hline Medium & 122 & 48.8 \\
\hline High & 79 & 31.6 \\
\hline Anambra-State-Njikoka-Low & 84 & 33.6 \\
\hline Medium & 123 & 49.2 \\
\hline High & 43 & 17.2 \\
\hline Onitsha South-Low & 90 & 36 \\
\hline Medium & 84 & 33.6 \\
\hline High & 76 & 30.4 \\
\hline Awka-Low TOTAL & 64 & 25.6 \\
\hline Medium & 112 & 44.8 \\
\hline High & 74 & 29.6 \\
\hline & 1500 & 100 \\
\hline
\end{tabular}


Table 5: Distribution of the respondents by Church Membership and Level of Education

\begin{tabular}{|c|c|c|c|c|c|c|c|c|c|}
\hline Churches & \multicolumn{2}{|c|}{ No Education \% } & \multicolumn{2}{|c|}{ Primary \% } & \multicolumn{2}{|c|}{ Secondary \% } & \multicolumn{2}{|c|}{ Higher \% } & University \% \\
\hline Qua Iboe & 3 & 5 & 1 & 1.67 & 13 & 21.67 & & 40 & $19 \quad 31.67$ \\
\hline Lutheran & 8 & 13.33 & 9 & 15 & 1 & 1.67 & 2 & 3.33 & $\begin{array}{ll}40 & 66.67 \\
\end{array}$ \\
\hline A.M.E Zion & 12 & 20 & 2 & 33.33 & 3 & 5 & 22 & 36.67 & 3 \\
\hline Mount Zion & 4 & 6.67 & 1 & 16.67 & 8 & 13.33 & 21 & 35 & $17 \quad 28.33$ \\
\hline Apostolic & 2 & 3.33 & 4 & 6.67 & & 6.67 & 19 & 31.67 & $\begin{array}{ll}31 & 51.67 \\
\end{array}$ \\
\hline RCCG & 2 & 3.33 & 2 & 3.33 & & 13.33 & 31 & 51.67 & $17 \quad 28.33$ \\
\hline The land of Truth & 5 & 8.33 & & 28.33 & 18 & 30 & 12 & 20 & $\begin{array}{ll}8 & 13.33 \\
\end{array}$ \\
\hline $\begin{array}{l}\text { City of Grace } \\
\text { Mission }\end{array}$ & 4 & 6.67 & & 20 & 4 & 6.67 & 18 & 30 & $22 \quad 36.67$ \\
\hline Eno Owo Ekong & & 16.67 & 5 & 8.33 & 32 & 53.33 & 9 & 15 & $8 \quad 13.33$ \\
\hline Churches & & Education \% & & nary $\%$ & $\mathrm{Sec}$ & ondary \% & $\mathrm{Hig}$ & er $\%$ & University \% \\
\hline $\begin{array}{l}\text { Mount Zion Light } \\
\text { House Full Gospel }\end{array}$ & 1 & 1.67 & 7 & 1.67 & 33 & 55 & & 6.67 & $15 \quad 25$ \\
\hline New Covenant & 3 & 5 & 1 & 6.67 & 36 & 60 & 4 & 6.67 & 11.67 \\
\hline Assemblies of God & 3 & 5 & 2 & 45 & & 3.33 & 16 & 26.67 & 20 \\
\hline $\begin{array}{ll}\text { Solid } & \text { Rock } \\
\text { Kingdom } & \end{array}$ & 1 & 1.67 & 1 & 1.67 & 15 & 25 & & 13. 33 & $35 \quad 58.33$ \\
\hline $\begin{array}{ll}\text { Liberty } & \text { Gospel } \\
\text { Ministry } & \\
\end{array}$ & 1 & 1.67 & 3 & 55 & 66 & 10 & 10 & 16.67 & $10 \quad 16.67$ \\
\hline Jehovah Witnesses & 7 & 11.67 & 3 & 5 & & 1.67 & 44 & 73.33 & 8.33 \\
\hline $\begin{array}{l}\text { Mountain of Fire } \\
\text { and Miracle }\end{array}$ & 1 & 1.67 & 1 & 25 & 13 & 21.67 & 23 & 38.33 & $\begin{array}{ll}8 & 13.33\end{array}$ \\
\hline
\end{tabular}

Table 6 Two Stage Ordinary Least- Square Analysis Results

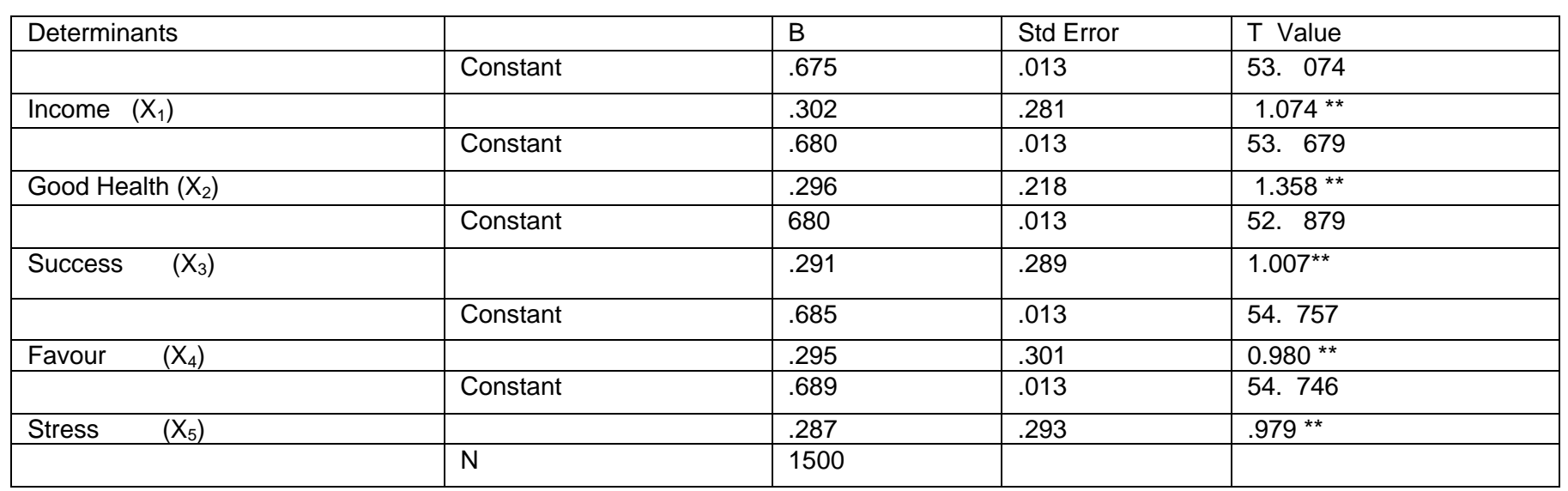

Where $P_{1}=$ Probabilities of existence/effect of witchcraft and $X_{t_{1}}$ to $X_{1_{5}}$ represented the determinants. Given that witchcraft powers was both instrumental and predictor of changes in $X_{1_{1}}$ to $X_{1_{5}}$ ** Implies a confidential Level of 95\% Multiple R 


\section{Correlation Matrix}

The results in table 6 (univariate analysis), tested at 95 percent confident level, were significant. Witchcraft or the power of witches and wizards relate with individual and family's income, health of people, success level, favour, and stress condition. The different types of witchcrafts: blind, white (Ukpong 2009) ruin individuals and families. If an individual is trapped, both his sources of income and promises are blocked. Frustration, hard luck, poor health, failure, and stress, among others are major characteristics or experiences of the individual. These are passed down to his relatives and children except delivered spiritually. According to the results (univariate) presented in the table (Table 6) as determined by the coefficients, witches and wizards directly and strongly influenced the income level, state of health, the degree of success, favour and stress level experienced by victims of witchcraft pandemonium.

As noted earlier, the people of Southeast Nigeria are predominantly Christians, who believe in the existence and ultimate power of God (Umoh, 2006). Christians also acknowledge the possibility of saints and evils congregating together wherever, as provided in the Holy Bible (Matthew 13: 24-30). Most of the respondents reported that witches and wizard were Christians. Cases of deaths and severe illnesses that occurred before and within the time of the study were blamed on the Christians who are witches; no traditionalist was reportedly accused of any person's misfortune throughout the period of the survey. In the Dr Congo, Molina (2005) observes that witchcraft has had little currently to do with traditional practices.

Because witches and wizards are of different kinds; blind and white; good and bad, their effects varied depending on the conditions characteristics of the victim. This is as illustrated by the results of bivariate regression. Findings of studies related to income status and health status of individuals and families (Allonsi 1992; Goldani, Barbieri, Bettiol, Barbieri \& Tomkins, 2001; Dooley and Curtis, 1998; Poerwanto, Stevenson \& de Klerk, 2003), for instance, posit that income level determines health status. In the study, measuring the effects of income level paired with health status on powers of witches and wizards produced an inverse result. The correlation coefficient (see table 4 b) not only of income and health, but in all paired cases, show an inverse relationship.
In Uruan Local Government Area of Akwa Ibom State, there is the popular saying "Ifot asese owo atta". This means, a witch is watchful in its attack. In the other two local government (Abak and Okobo) as in others, "Ufok imo" asuk ado ufok imo meaning a family which has the history of being wealthy ever remains wealthy. One who is born into such a family is automatically wealthy. Equally, "ufok ubom asuk ado ufok ubom. This translates to mean that a healthy family remains ever healthy, hence one who was lucky to share ancestry in a healthy family was also healthy. It is contestable the fact that witches and wizards could turn riches to wretched and ruin, and not vice versa. That the belief about certain types of witchcraft held by the southeast people of Nigeria relating to their income and health status do not fade, create course for investigating the implications of witchcraft practice on family socio- economic status. Success like health status depends on income level and when paired inversely relates with powers of witchcraft. That is, high income spurs success and subdues the power of witchcraft. High income and successful people believe less on power of witchcraft and vice versa. Natural tendencies exist as observed in the study area where people with low and medium income live successful lives. The inverse relationship applies: the success suppresses acceptance of the existence of witches and wizards until when fortune changes. Favour is another indicator of power of witchcraft. Result of data analysis shows that income correlates with favour to influence indirectly the effect of witchcraft attack on the individual. As one was likely to get favour from others, quite negative were his views about witchcraft's strength and powers. Most of the respondents, in the urban areas of Onitsha and Awka in Anambra State, comprising those who claimed witches and wizards had no powers over them and those who never experienced stress in life, were furious about the question that witchcraft powers exert on true Christians.

Stress is both a predictor and determinant of many diseases. People often exposed to unnecessary and difficult stress are at risk of diseases and death. Insanity, hypertensive disorder, cardiac arrest, among others are consequences of stress. These were also reported by the respondents to be products of witchcraft attack. Witches and wizards are also believed to cause infertility in men and women, mortality of infant, child, mothers and adults. Hence, for individuals who were less stressful and have high income, witchcraft hits less; but for those who where less stressful and have low income, witchcraft hits more. The study also carried out multivariate analysis

\section{3}


(where each one of the variables were held constant) to determine if the direction of effect or relationship was as a result of pairing only two variables and whether the direction could change if more than two variables were paired. According to the (multivariate analysis) regression results (see Table $6 \mathrm{c}$ ), with holding the effect or contribution of every one variable out of the five equally indicates on inverse effects.

\section{RECOMMENDATION}

This study recommends that cases of witchcraft if truly authenticated must be handled by experts who are spiritually endowed by the Divine. Rather than rush to conclusions that witches are the cause of certain problems, scientific solutions should be sought. The experts who can deal with the Devil and its agents in the Christian tradition are known as Exorcists. In Southeast Nigeria where witches are most feared, groups of churches should identify Exorcists and create authentic centre for exorcism to deal with cases of witchcraft when so properly identified rather than castigate and kill suspected witches. In addition, Christian counseling centers with trained counselors are important in the cultural milieu of Southeast Nigeria to help battle with the issues of witchcraft. In addition, we also propose that for people to succeed in their quest for sustainable development and liberation against witches, they should learn not to look up to any models, but they need to cultivate confidence in themselves, such that their actions spring from themselves rather than being motivated by imitation of any role models (Oduyoye \& Kanyoro 1992). The power of positive thinking and believing in oneself is a powerful weapon to fight imaginary or real witches. These strategies will lead to sustainable development in Nigeria.

\section{CONCLUSION}

The numerous churches in Southeast Nigeria have done well in taking care of the less privileged, the oppressed and the marginalized in the society. Some churches are committed to providing the much needed care for the sick and the aged, the prisoners, street children. The run rehabilitation centers, schools, orphanages, hospitals and many other humanitarian services. However, this study reveals that the traditional belief in witchcraft need to be addressed by the churches more seriously. Many cases attributed to witches are not necessarily true. Education is important to help people know the true causes of human problems rather than push every issue to the door step of Satan and its agents- the witches. The Churches in Nigeria need to know that undue attribution of issues to witches will definitely slow down economic growth, political advancement, scientific and technological development and social progress. Witches and Wizards are believed to distort development and its process. For fear of attack through witchcraft, people hide their strength (wealth and income). Since the people in the study area say that evidence abounds that in the rural villages home absentees who come back to establish business and or build houses die in the process or face serious challenges that lead to abandon projects, the belief in the power of witchcraft cannot be safely ignored but need to be addressed by the numerous Churches in the area in the light of the above recommendations.

\section{REFERENCES}

Allonsi, B. A. (1992). "Development Implications of Early Mortality Factors in Nigeria". Journal of Social Development in Nigeria, 7 (1), 67 - 85.

Asamoah-Gyadu, Kwabena, J. (1998),'The Church in the African State: The Pentecostal/Charismatic Experience in Ghana', Journal of African Christian Thought, Vol. 1, (2), 51-57.

Cox, H. (1994). Fire from Heaven: The Rise of Pentecostal Spirituality and the Shaping of Religion in Twenty First Century, Cambridge, MA: Da Capo Press.

Dooley, M. D. \& Curtis, L. (1998). "Child Health and Family Socio-Economic Status in the Canadian National Longitudinal Survey of Children and Youth". Downloaded from (Website: http://www.demographicresearh.org)

Ehusani, G.O. (1996) A Prophetic Church. Provincial Pastoral Publications, Ede, Nigeria. 103.

Enang K. (1979). The African Experience of Salvation: Based on the Annang Independent Churches of Nigeria. M\&C Publishers, London.

Essien, D.P (1999) The Sorrows of Eve: Gynecological Disorders and Related Health Problems of women. Desmac Publication, Abak, Nigeria

Exodus 22:18 ( The Scripture Reference Study Bible)

Goldani, M.Z.; Barbieri, M. A.; Bettiol, H.; Barbieri, M. R. \& Tomkins, A. (2001). "Infant Mortality Rate According to Socio-Economic Status in a Brazilian City". Rev. Saude Publica, 35 (2). Downloaded from (Website: http://www.demographic-researh.org)

Irvine, D (2005) From Witchcraft to Christ. Kingsway Communications Limited.

James 2: 20 (The Scripture Reference Study Bible)

Marshall, R (2009) Political Spiritualities The University of Chicago Press, Chicago and London. (2) 
(1995). "'God is not A Democrat": Pentecostalism and Democratisation in Nigeria', In Paul Gifford (ed), Christianity and Africa's Democratisation, Leiden: Brill Publications, 239-260.

(1993)."'Power in the Name of Jesus": Social Transformation and Pentecostalism in Western Nigeria "Revisited"', in Terence Ranger and Olufemi (eds), Legitimacy and the State in Twentieth Century Africa: Essay in Honour of A. H. M. Greene, London: Macmillan Press, $213-246$.

, (1992). "Pentecostalism in Southern Nigeria: An Overview", in Paul Gifford (ed), New Dimension in African Christianity, Ibadan: Sefer Publications, 7-32.

, (1991). 'Power in the Name of Jesus', Review of African political Economy, nr. 52, 21 -38.

Matthew 13: 24-30 ( The Scripture Reference Study Bible)

Molina, J. A. (2005). The Invention of Child Witches in the Democratic Republic of Congo. Summary of the research and experiences of save the children's 2003 - 2005 programme funded by USAID.

Obiora, F. K. (1998). The Divine Deceit: Business in Religion. Optimal Publishers, Enugu - Nigeria. 14

Oduyoye M.A.; Kanyoro M. R.A. (1992) The will to Arise: Women, Tradition, and the Church in Africa. Orbis Books. Maryknoll, United States of America. 185.

Ogunjuyibe, P. O. (2004). "Perception and Attitude of the Yorubas Towards the Existence of 'Abiku' ". Demographic research, II (2). Downloaded from (Website: http://www.demographic-researh.org)
Offiong, D. A. (1983). "Social Relations and Witch Beliefs Among the Ibibio of Nigeria". Journal of Anthropological Research, 39 (1).

Ojo, M. (1986). 'The Growth of Campus Christianity and Charismatic Movements in Western Nigeria', Ph. D. Dissertation, University of London.

Okai M.O. (2008) Religion and Social Conflict Management the Case of the Niger Delta Region of Nigeria. Cal Integrated Resources Limited, Port Harcourt Nigeria.

Okere T. (2005) Church, Theology and Society in Africa. Fourth Dimension Publishing Co. Enugu Nigeria. 177178

Poerwantto, S.; Stevenson, M. \& de Klerk, N. (2003). "Infant Mortality and Family Welfare: Policy Implications for Indonesia". Epidemiol Community Health, 1 (57), 493 - 498.

Udoh B. E.O. (2008) Religion and Society Socio-Ethical, Religious and Cultural Life of Ibibio People. OKMAN Publishers Aba, Nigeria

Ukah, A. (2008) A. New Paradigm of Pentecostal Power. Africa World Press.

Ukpong, P. A. (2009). An Enquiry into Culture: Ibibio Names. Uyo: Dorand Publishers.

Umanah, H. (1996). Communication and Social Transformation. Uyo: Sanuf Nigeria.

Umoh, J. O. (2006) African Traditional Religion: A Core Nigerian Heritage. In Essoh, P.A. \& Oluwabamide, A.J. (2006). Highlight of the Nigerian Cultural Heritage. Lagos: Lisjohonson Resources. 